[Radiocarbon, Vol. 21, No. 3, P. 329-338]

\title{
ANU RADIOCARBON DATE LIST VII
}

\section{H A POLACH, B G THOM,* and G M BOWMAN*}

\author{
Compiled by Stella Wilkie
}

\author{
Radiocarbon Dating Research Laboratory, Australian National \\ University, Canberra, Australia
}

Along SE coast of Australia a variety of Holocene barriers composed of siliceous sand and shell detritus occur within bedrock-confined embayments. On basis of morphostratigraphy 4 barrier types are recognized: prograded, stationary, receded and episodic transgressive dunes. Several subtypes are also distinguished. Composite bay barriers involving partial eolian reworking of a prograded barrier constitute most complex examples of Holocene depositional sequences on this coast. The present list is a preliminary attempt at defining the age structure of a group of such barriers (excepting receded type). Ages are reported in conventional years $\mathbf{B P}$. Text references to ages and age ranges are environmental effect corrected

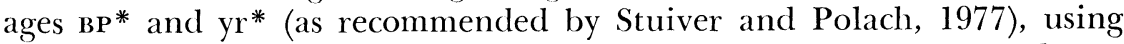
$450 \pm 35 \mathrm{yr}$ as postulated by Gillespie and Polach (in press) in order to relate Australian oceanic environment shells to terrestrial environment wood. $\delta^{13} \mathrm{C}$ errors, where based on measurement, are always $\pm 0.2 \%$ and are not shown in the text; when based on estimated values (Est) the error is given.

Samples were obtained by power-auger drilling, coll by B G Thom, Dept Biogeog and Geomorph, Australian National University and G M Bowman, Geography Dept, Sydney University, and subm by Dept Biogeog and Geomorph. Except where noted, cleaned shelly sand or shell sample was hydrolyzed with $\mathrm{HCl}$ under vacuum and released $\mathrm{CO}_{2}$ recovered for further processing prior to ${ }^{14} \mathrm{C}$ analysis.

Reworking of mollusks and their redeposition at a later date in the sediment body in a dynamic nearshore or beach face environment have been considered by Bernard et al (1962) and Curray et al (1969). These workers have designated certain samples "anomalously old". However, in this list, consistency of pattern is prime guide to assessing reworking effect. In areas studied in detail (eg, Moruya, see fig 1), failure to find young dates below upper shoreface deposits limits the likelihood of all dates being reworked; all Holocene dates are assumed to date the period of deposition unless otherwise stated.

\section{ACKNOWLEDGMENTS}

We wish to acknowledge the significant contribution to the management of the laboratory made by J Golson who is Chairman of the ANU Radiocarbon Committee. Mass spectrometry was carried out by HAP at the University of Waikato, Dept of Chemistry, Hamilton, New Zealand, and we wish to thank A T Wilson for permission to do so. The excellent

* Dept Geography, Faculty of Military Studies, University of New South Wales, Duntroon, ACT 2600 
work of the laboratory's senior staff, John Head and John Gower, made this report possible.

\section{Moruya series}

\section{Prograded Barriers}

Located N of Moruya R, New South Wales ( $35^{\circ} 53^{\prime} \mathrm{S}, 150^{\circ} 09^{\prime} \mathrm{E}$ ). Narrow drainage basins sculptured into folded Palaeozoic metasediments, which are locally capped by Tertiary basalts and fluvial gravels, are blocked by bay-head barrier which is composed of 40-50 beach ridges. Four ${ }^{14} \mathrm{C}$ dates on shell hash and organic muds were obtained from the transgressive facies. Eighteen ${ }^{14} \mathrm{C}$ dates on shell fragments were obtained from nearshore regressive unit, from which 5 age groups (4 relic, 1 modern) have been id (fig 1).

ANU-1117. $\quad D^{14} \mathrm{C}=-531.9 \pm 4.4 \%$

Shell hash (1240 min count).

ANU-1118. $\quad D^{14} \mathrm{C}=-\mathbf{5 2 1 . 7} \pm \mathbf{4 . 4} \%$

Shell hash (1320 min count).

ANU-1197. $\quad D^{14} \mathrm{C}=-\mathbf{5 1 8 . 0} \pm \mathbf{4 . 3} \%$

Shell hash (1460 min count).

ANU-1119. $\quad \mathrm{D}^{14} \mathrm{C}=\mathbf{- 5 1 5 . 2} \pm \mathbf{5 . 5} \%$ 。

Shell hash (760 min count).

ANU-1198. $\quad D^{14} \mathrm{C}=-\mathbf{5 1 5 . 9} \pm \mathbf{4 . 3} / \% o$

Shell hash (1480 min count).

ANU-1200. $\quad D^{14} \mathrm{C}=\mathbf{5 4 2 . 8} \pm \mathbf{4 . 6} \%$

Shell hash (1180 min count).

ANU-1116. $\quad D^{14} \mathrm{C}=-\mathbf{4 5 8 . 8} \pm \mathbf{4 . 5} \%$

Shell hash (1300 min count).

ANU-1199. $\quad D^{14} \mathrm{C}=-\mathbf{4 7 1 . 1} \pm \mathbf{5 . 0} \%$

Shell hash (1100 min count).

ANU-1400. $\quad D^{14} \mathrm{C}=\mathbf{- 4 8 9 . 9} \pm \mathbf{5 . 4} \%$

Shell hash (880 min count).

ANU-1138. $\quad D^{14} \mathrm{C}=-475.5 \pm 4.1 \%$

Shell hash (1820 min count). $\mathbf{6 1 0 0} \pm \mathbf{8 0}$
$\delta^{13} C=+1.1 \%$

$5920 \pm 70$

$\delta^{13} C=+1.1 \%$ 。

$\mathbf{5 8 6 0} \pm \mathbf{7 0}$

$\delta^{13} C=+0.6 \%$ 。

$5820 \pm 90$

$\delta^{13} C=+1.3 \%$ o

$\mathbf{5 8 3 0} \pm \mathbf{7 0}$

$\delta^{13} C=+1.2 \%$ o

$6290 \pm 80$

$\delta^{13} C=+0.6 \%$ o

$4930 \pm 70$

$\delta^{13} C=+1.2 \%$ o

$5120 \pm 80$

$\delta^{13} C=+1.1 \%$ o

$5410 \pm 90$

$\delta^{13} C=+1.1 \%$ o

$5180 \pm \mathbf{6 0}$

$\delta^{13} C=+0.8 \%$ 。 


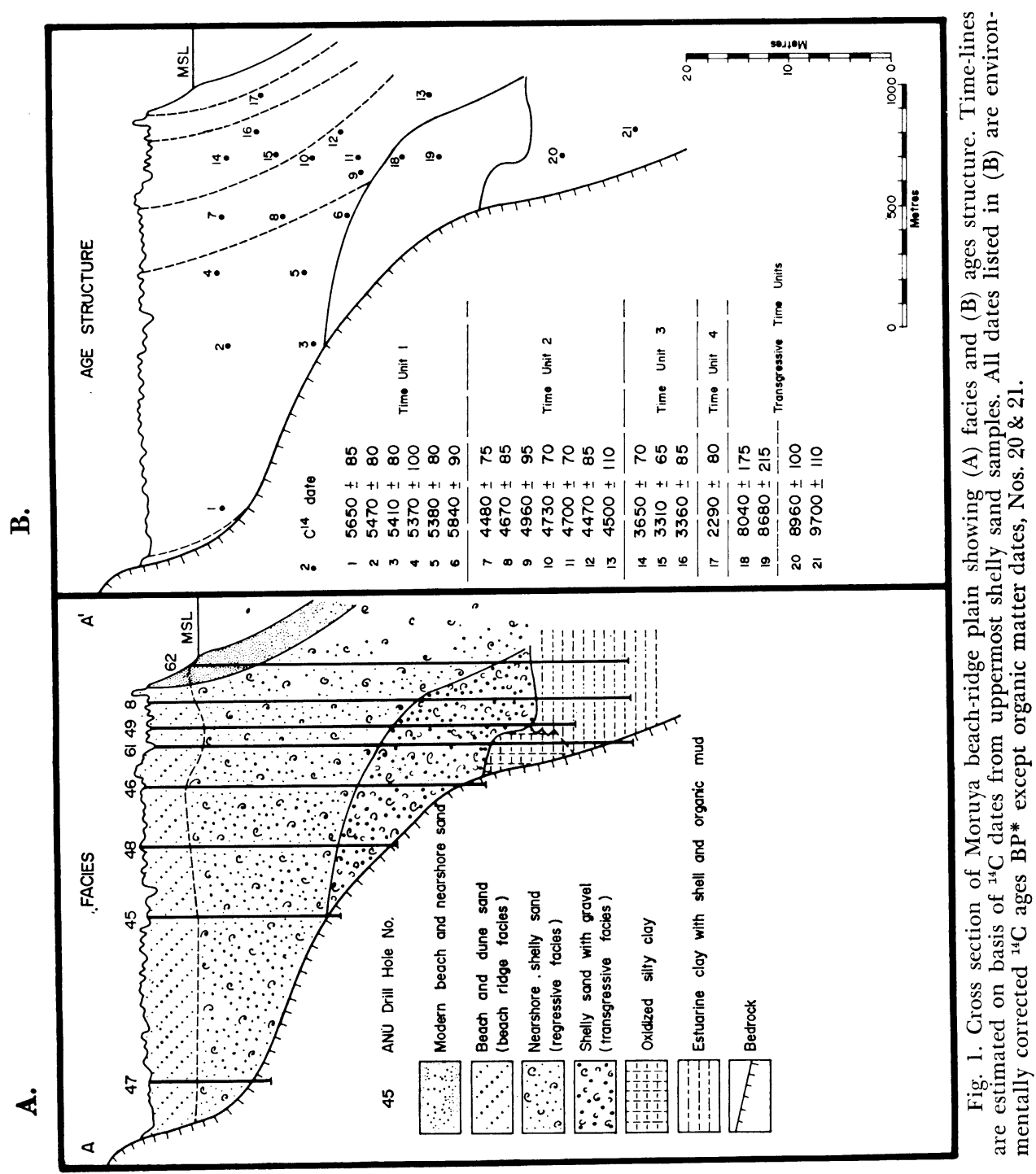


ANU-1139. $\quad \mathrm{D}^{14} \mathrm{C}=-\mathbf{4 7 3 . 2} \pm \mathbf{4 . 0} \%$

$$
5150 \pm 60
$$

Shell hash (1960 min count).

$$
\delta^{13} C=+1.1 \% \text { o }
$$

ANU-1398. $\quad D^{14} \mathrm{C}=-458.3 \pm 5.5 \%$$$
\text { Est } \delta^{13} C
$$

Shell hash (900 min count).

ANU-1399. $\quad D^{14} \mathrm{C}=-460.2 \pm 6.9 \%$

Shell hash (680 min count).

ANU.1115. $\quad D^{14} \mathrm{C}=-399.9 \pm 4.7 \%$ 。

Shell hash (1320 min count).

ANU-1137. $\quad D^{14} \mathrm{C}=-\mathbf{3 7 4 . 0} \pm 4.3 \%$

$$
3760 \pm 60
$$

Shell hash (1920 min count).

ANU-1114. $\quad D^{14} \mathrm{C}=-377.4 \pm 6.1 \%$

$\mathbf{3 8 1 0} \pm \mathbf{8 0}$

Shell hash (1080 min count).

ANU-1397. $\quad \mathrm{D}^{14} \mathrm{C}=-\mathbf{2 8 9 . 4} \pm 6.1 \%$

Shell hash (880 min count).

ANU-1140. $\quad D^{14} \mathrm{C}=-\mathbf{6 5 2 . 4} \pm \mathbf{7 . 4} \%$

$8490 \pm 170$

Shell hash. Dilution, 40\% sample (1980 min count).

ANU-1141. $\quad D^{14} \mathrm{C}=-\mathbf{6 7 8 . 9} \pm \mathbf{8 . 1} \%$

$9130 \pm 210$

$\delta^{13} \mathrm{C}=+0.9 \%$

Shell hash. Dilution, 39\% sample (2000 min count).

ANU-1133. $\quad D^{14} \mathrm{C}=-672.1 \pm 4.0 \%$

$$
8960 \pm 100
$$

Est $\delta^{13} C=-24.0 \pm 2.0 \%$

Organic mud, boiled in 2N HCl (1740 min count).

ANU-1132. $\quad D^{14} \mathrm{C}=-\mathbf{7 0 0 . 8} \pm \mathbf{3 . 9} \%$

Organic mud, boiled in $2 \mathrm{~N} \mathrm{HCl}$ (1720 min count).

ANU-1523. $\quad D^{14} \mathrm{C}=-\mathbf{4 3 5 . 4} \pm \mathbf{5 . 3} \%$

$$
4590 \pm 80
$$

Shell hash (1020 min count).

General Comment (BT): Holocene depositional history of Moruya embayment may be summarized as follows: 1) Between ca 10,000 and 8500 ${ }^{14} \mathrm{C}$ yr* ago a low-relief barrier stood 30 to $40 \mathrm{~m}$ below present sea level and seaward of present shoreline. Estuarine sediments accumulated be- 
hind this transgressing barrier. Vertical and landward growth of barrier may have ceased between ca 8500 and $8000{ }^{14} \mathrm{C}$ yr*. 2) Rapid marine transgression from 8000 to $6000{ }^{14} \mathrm{C}$ yr* took sandy open-ocean shoreline to the head of the embayment, blocking off narrow drowned valleys in which estuarine shelly muds were rapidly accumulating. 3) From close to 6000 to ca $2500{ }^{14} \mathrm{C}$ yr* ago shoreline prograded by mechanism of multiple beach-ridge formation. Pattern of progradation was episodic. Four phases have been recognized. First resulted in deposition of more than half beach-ridge plain. This led to a marked change in environmental conditions in drowned valleys from estuarine to freshwater swamp. 4) Relative shoreline stability has characterized last $2500{ }^{14} \mathrm{C}$ yr* in embayment during which a complex hummocky foredune has formed.

\section{Fens series}

$\mathrm{N}$ of Port Stephens $\left(32^{\circ} 38^{\prime} \mathrm{S}, 152^{\circ} 12^{\prime} \mathrm{E}\right)$, New South Wales. Embayment contains (Pleistocene) Inner and (Holocene) Outer Barriers. Both barriers composed of well-developed sets of beach ridges (LangfordSmith and Thom, 1969, pl III). An interbarrier depression 1 to $2 \mathrm{~km}$ wide, occupied in part by diverted Lower Myall R, separates 2 barriers. Outer Barrier beach-ridge plain is $1 \mathrm{~km}$ wide and contains 20 ridges. Dates are on Outer Barrier and interbarrier depression samples.

ANU-1665. $\quad D^{14} \mathrm{C}=-492.2 \pm 6.9 \%$ $\mathbf{5 4 4 0} \pm 110$

Shell hash (1040 min count).

ANU-1527. $\quad \mathrm{D}^{14} \mathrm{C}=-\mathbf{5 8 3 . 5} \pm \mathbf{1 1 . 2} \%$

$\mathbf{7 0 4 0} \pm 220$

$\delta^{13} C=+1.1 \%$ o

Shell hash. Dilution, 27\% sample (1520 min count).

ANU-1666. $\quad D^{14} \mathrm{C}=-499.4 \pm 6.2 \%$

$5560 \pm 100$

Shell hash (1040 min count).

ANU-1335. $\quad D^{14} \mathrm{C}=-\mathbf{5 2 8 . 2} \pm \mathbf{3 0 . 1}_{/ \%}^{\%}$

$\mathbf{6 0 3 0} \pm \mathbf{5 3 0}$

Est $\delta^{13} C=+1.0 \pm 1.0 \%$

Shell hash. Dilution, $10 \%$ sample (1300 min count).

ANU-1336. $\quad D^{14} \mathrm{C}=-462.8 \pm 21.7 \%$ 。

$4990 \pm 330$

Shell hash. Dilution, 14\% sample (1500 min count).

ANU-1528. $\quad D^{14} \mathrm{C}=-463.3 \pm 6.4 \%$

$5000 \pm 100$

Shell hash (1000 min count).

ANU-1529. $\quad D^{14} \mathrm{C}=-\mathbf{5 9 5 . 4} \pm \mathbf{9 . 8} \%$

$7270 \pm 200$

Shell hash. Dilution, $34 \%$ sample (1460 min count). 
ANU-1531. $\quad D^{14} \mathrm{C}=-411.1 \pm 13.2 \%$ o

$4250 \pm 180$

Shell hash. Dilution, $25 \%$ sample (1440 min count).

ANU-1532. $\quad \mathrm{D}^{14} \mathrm{C}=-\mathbf{4 0 3 . 7} \pm \mathbf{5 . 4} \%$ o

$4150 \pm 70$

Shell hash (1040 min count).

$\delta^{13} C=+1.6 \%$

ANU-1530. $\quad D^{14} \mathrm{C}=-\mathbf{5 3 2 . 0} \pm \mathbf{5 . 0} \%$ 。

$6100 \pm 90$

$\delta^{13} C=+1.5 \%$ 。

Shell hash (1000 min count).

General Comment (BT\&GB): minimum ANU ${ }^{14} \mathrm{C}$ dates, and others (Thom et al, 1978) from nearshore facies show that most Outer Barrier progradation occurred during the period 5000 to $3300{ }^{14} \mathrm{C}$ yr BP*. Barrier appears to have ceased growing seaward since that period, or alternatively, has been eroded back to its present position removing later phases of progradation.

Age structure of 'backbarrier' or quiet-water interbarrier deposits suggests near vertical growth between 7000 and $5000{ }^{14} \mathrm{C}$ BP*. From mollusk composition a sandy partially enclosed bay is inferred which opened to $S$ toward Port Stephens. Rich shelly facies rise close to present sea level in that direction. At site of section this unit dates 6800 to $6600{ }^{14} \mathrm{C}$ yr $\mathbf{B P} *$ at $13 \mathrm{~m}$ below MSL (ANU-1527, -1529 ), but $4 \mathrm{~km}$ to $\mathrm{S}$, at $-4 \mathrm{~m}$ MSL a similar fauna dates $4990 \pm 115{ }^{14} \mathrm{C}$ yr BP* (ANU-1665).

Following stages can be recognized in develop of Outer Barrier at Fens: 1) A low relief barrier that only partially enclosed a faunal-rich sandy bay was initiated within Fens embayment at least $7000{ }^{14} \mathrm{C} \mathrm{BP}^{*}$, when sea level was ca 10 to $15 \mathrm{~m}$ below its present position. 2) After sea level reached its present position, ca $6000{ }^{14} \mathrm{C}$ yr BP**, a narrow, low sand barrier probably formed a highly mobile open-ocean shoreline, subjected to periodic washover and eolian instability. Relevant date is ANU-1530 $\left(5650 \pm 95{ }^{14} \mathrm{C}_{\mathrm{yr} \mathrm{BP}} *\right.$ ). 3) First phase of progradation occurred between 5000 and $4500{ }^{14} \mathrm{C}$ yr BP*. Critical dates for this event are ANU-1336 and GaK-1469, -1470 (see Thom et al, 1978) from within nearshore shelly facies and ANU-1528 on estuarine shells near contact with coarse beach sands. 4) Along seaward margin of Outer Barrier over last $3000{ }^{14} \mathrm{C}$ yr* or so a complex foredune has developed which is now undergoing extensive eolian erosion, esp at $\mathrm{N}$ end.

\section{Wonboyn series}

Embayment at Wonboyn on far S coast of NSW (37 $16^{\prime} \mathrm{S}, 149^{\circ} 57^{\prime}$ E) has extensive beach-ridge plain which is $1.6 \mathrm{~km}$ wide and contains $\max$ of 60 beach ridges.

ANU-1396. $\quad \mathrm{D}^{14} \mathrm{C}=-\mathbf{3 6 2 . 2} \pm \mathbf{1 0 . 5} \%$

$3610 \pm 130$

Shell hash. Dilution, $38 \%$ sample (1080 min count). 
ANU-1584. $\quad D^{14} \mathrm{C}=-315.9 \pm 7.9 \%$

$3050 \pm 90$

$\delta^{13} C=+1.4 \%$ o

Shell hash (980 min count).

ANU-1585. $\quad D^{14} \mathrm{C}=\mathbf{- 5 2 1 . 8} \pm \mathbf{5 . 0} \%$

$\mathbf{5 9 3 0} \pm 90$

Shell hash (1000 min count).

$\delta^{13} C=+1.4 \%$

General Comment (BT\&GB): sample ANU-1585 (5480 \pm 95 уr вР*) coll from beneath inner edge of beach-ridge plain $1.4 \mathrm{~km}$ from shoreline is consistent with ages from other sites of regressive shelly sands loc at rear of Outer Barriers. Wonboyn plain shows younger ages towards present shoreline with ANU-1396 (3160 $\left.\pm 135 \mathrm{yr}^{\mathrm{BP}}{ }^{*}\right)$ at $600 \mathrm{~m}$ inland and ANU-1584 $\left(2600 \pm 100 \mathrm{yr} \mathrm{BP}^{*}\right)$ at $500 \mathrm{~m}$.

\section{Merimbula}

Stationary Bay Barriers

On S coast New South Wales $\left(36^{\circ} 54^{\prime} \mathrm{S}, 149^{\circ} 54^{\prime} \mathrm{E}\right)$. Although barrier possesses a few beach ridges, its narrow width $(<300 \mathrm{~m})$, wide backbarrier flat, and arrangement of facies, are typical of stationary bay barriers (Thom et al, 1978). In comparison with extensive beach-ridge plains, Merimbula barrier is relatively high, averaging 8 to $10 \mathrm{~m}$ above MSL. Barrier consists of a thin wedge of near-shore shelly sand overlain by leached, well-sorted quartzose sands. However, shelly sands are not as clearly graded coarse to fine downward as in case of prograded barriers. A ${ }^{14} \mathrm{C}$ date of $5530 \pm 85{ }^{14} \mathrm{C}$ yr BP* (ANU-1404) has been obtained from seaward side of barrier at depth of $7 \mathrm{~m}$ below MSL.

ANU-1404. $\quad D^{14} \mathrm{C}=-\mathbf{5 2 5 . 0} \pm \mathbf{4 . 5} \%$ $\quad \mathbf{5 9 8 0} \pm \mathbf{8 0}$

$\delta^{13} C=+1.4 \%$ o

Shell hash (1380 min count). Comment (BT): stratigraphic pattern at Merimbula and other localities where stationary bay barriers have been drilled suggests 2 main phases of deposition. First commenced as transgressing Holocene sea entered embayments. Between ca 8000 and 7000 ${ }^{14} \mathrm{C}$ yr* ago transgressive barrier beach facies started to accumulate vertically as well as recede slowly inland. Behind beach washover processes initiated deposition of a relatively thick backbarrier sand facies (up to $20 \mathrm{~m}$ ). Second phase of barrier development occurred after sea level reached its present position (ca $6000{ }^{14} \mathrm{C}$ yr BP* $)$. During this phase backbarrier deposition became a less active process as foredune ridges grew in height. Progradation, if it took place at all, occurred ca $5500{ }^{14} \mathrm{C}$ yr* ago. Thus, present shoreline position of stationary bay barriers dates from ca $5000{ }^{14} \mathrm{C} \mathrm{yr} \mathrm{BP*}$.

\section{Eurunderee}

\section{Episodic Dune Barries}

At Eurunderee, near Myall Lakes $\left(32^{\circ} 29^{\prime} \mathrm{S}, 152^{\circ} 22^{\prime} \mathrm{E}\right)$, Holocene Outer Barrier is composed of active sand blowouts and stabilized parabolic dunes. Elongate blowouts up to $1 \mathrm{~km}$ in length penetrate $\mathrm{N}$ along troughs and up terminal walls of stabilized parabolic dunes (Thom, 1965, 
pl 1), most landward side of Outer Barrier overlies peats of interbarrier depression which date $3620 \pm 130{ }^{14} \mathrm{C}$ yr BP (ANU-1673).

ANU-1673. $\quad D^{14} \mathrm{C}=-\mathbf{3 6 2 . 8} \pm 6.3 \%$

$3620 \pm 130$

Est $\delta^{13} \mathrm{C}=-24.0 \pm 2.0 \%$

Organic soil, treated with hot HCl (980 min count). Comment (BT): episodic dune bay barriers contain either a predominantly eolian sequence both above and below sea level, or a transgressive-regressive marine sand sequence below sea level covered by mid- to late-Holocene dunes (eg, Bherwerre; Thom et al, 1978). In both cases, buried peats and soils, plus morphologic "nesting", attest to episodes of transgressive dunes (parabolic or long-walled types) followed by phases of vegetation stabilization of freemoving sand surfaces.

\section{Newcastle Bight series}

$$
\text { Composite Bay Barriers }
$$

Newcastle Bight, $\mathrm{N}$ coast of New South Wales $\left(32^{\circ} 48^{\prime} \mathrm{S}, 151^{\circ} 55^{\prime} \mathrm{E}\right)$ is best studied example of a composite barrier. Morphologically barrier consists of a small area of beach-ridge plain exposed at $\mathrm{E}$ end and 3 longwalled transgressive ridges ( 2 stabilized plus seaward ridge, still mobile) which have overrun rest of barrier. 5 cross-sections have established gen stratigraphy (Ly, 1976) and show characteristic arrangement of sedimentary facies beneath barrier. Thom et al $(1978$, figs 8,9$)$ give morphologic map of area.

Inner Barrier surface lies buried by shelly transgressive sand sheet from which 4 dates have been obtained: $9520+1590-1330{ }^{14} \mathrm{C}$ yr BP* (ANU-1330), $8500 \pm 145{ }^{14} \mathrm{C}$ yr вP* (ANU-1676), $8260 \pm 295{ }^{14} \mathrm{C} \mathrm{BP}^{*}$ (ANU-1526) and $8100 \pm 165{ }^{14} \mathrm{C}$ yr BP* (ANU-1677). Above this sheet is a wedge-shaped unit composed of near-shore shelly sand. Early midHolocene phase of progradation suggested by $6070 \pm 125{ }^{14} \mathrm{C}$ yr $\mathrm{BP}^{*}$ (ANU-1525). ANU-1675 (6770 $\pm 225{ }^{14} \mathrm{C}$ yr BP*) is also from this unit, but shell sample was probably reworked from older deposit. From within mobile dunes, an in situ tree stump was exhumed on deflated windward side and yielded age of $300 \pm 70{ }^{14} \mathrm{C}$ yr BP (ANU-1331). There is no evidence of beach ridges amongst long-walled ridges, but landward stabilized long-walled ridge (Ridge I) has clearly overrun beach ridges to $\mathrm{N}$ and $\mathrm{E}$. Ridge I also directly overlies either estuarine muds, containing a rich molluskan fauna (ANU-1332, $4310 \pm 105{ }^{14} \mathrm{C}$ yr BP*), or backbarrier flat sands, on its landward side. Second vegetated long-walled ridge (Ridge II) more or less parallels shoreline and rests upon beach and nearshore sand facies. Seaward, active ridge front of mobile dune sheet (Ridge III) is burying old beach ridges at $\mathrm{E}$ end of barrier, transgressing swampy deflation surface of Ridge II. Figs 8 and 9, Thom et al (1978) show these features.

$$
\text { ANU-1330. } \quad D^{14} \mathrm{C}=-\mathbf{7 1 0 . 9} \pm \mathbf{5 1 . 5} \% c
$$

Shell hash. Dilution, $6 \%$ sample (900 min count). 
ANU-1526. $\quad D^{14} \mathrm{C}=-661.9 \pm 11.9 \%$

$8710 \pm 290$

Shell hash. Dilution, $28 \%$ sample (1220 min count).

$\delta^{13} \mathrm{C}=+1.8 \%$

ANU-1525. $\quad D^{14} \mathrm{C}=-\mathbf{5 5 6 . 0} \pm 6.8 \%$

$6520 \pm 120$

$\delta^{13} \mathrm{C}=+1.4 \%$

Shell hash (1020 min count).

ANU.1332. $\quad D^{14} \mathrm{C}=-447.2 \pm 6.7 \%$

$4760 \pm 100$

Shell hash (1280 $\mathrm{min}$ count).

$\delta^{13} C=+1.9 \%$

ANU-1675. $\quad D^{14} \mathrm{C}=-\mathbf{5 9 2 . 8} \pm \mathbf{1 0 . 8} \%$ o

$7220 \pm 220$

$\delta^{13} C=+1.5 \%$ o

Shell hash. Dilution, $34 \%$ sample (1020 min count).

ANU-1676. $\quad D^{14} \mathrm{C}=-671.8 \pm 5.6 \%$

$8950 \pm 140$

$\delta^{13} C=+1.1 \%$

Shell hash (1040 min count).

ANU-1677. $\quad D^{14} \mathrm{C}=-655.1 \pm 6.7 \%$

$8550 \pm 160$

$\delta^{13} C=+1.1 \%$

Shell hash (1040 min count).

ANU-1678. $\quad D^{14} \mathrm{C}=-\mathbf{7 0 2 . 1} \pm \mathbf{4 . 3} \%$

$9730 \pm 120$

$\delta^{13} C=+0.5 \%$

Shell hash (1020 min count).

ANU-1679. $\quad D^{14} \mathrm{C}=-970.1 \pm 6.8 \%$

$28,180 \pm 2100$

$\delta^{13} C=0.0 \%$ o

Shell hash. Dilution, $40 \%$ sample (1440 min count).

ANU-1331. $\quad D^{14} \mathrm{C}=-\mathbf{3 6 . 0} \pm \mathbf{7 . 8} \%$ 。

$\mathbf{3 0 0} \pm \mathbf{7 0}$

Wood (1020 min count).

$$
\text { Est } \delta^{13} C=-24.0 \pm 2.0 \%
$$

General Comment (BT\&GB): 1) Basal transgressive shelly sand facies at $-40 \mathrm{~m}$ overlies oxidised pre-Inner Barrier clay. Shells date 27,730 \pm 2100 ${ }^{14} \mathrm{C}$ уг вP* (ANU-1679), which, if assumed to reflect true age of deposition, supports est of $-41 \pm 1 \mathrm{~m}$ for the $28,000 \mathrm{yr} \mathrm{BP}^{*}$ low sea level determined from Reef complex II on the Huon Peninsula (Bloom et al, 1974). 2) Noncalcareous sand $4 \mathrm{~m}$ thick, here interpreted as a nearshore-beach sand leached during Last Glacial sea level min. 3) Slightly muddy sand, rich in estuarine or open bay mollusks, at -25 to $-30 \mathrm{~m}$, could reflect backbarrier sedimentation 9000 to $10,000{ }^{14} \mathrm{C}$ yr* ago (ANU-1678). 4) Shelly sand facies, quite coarse and containing granules, assoc with last phase of marine transgression. Shells which date $8100 \pm 165{ }^{14} \mathrm{C}$ yr вP* (ANU-1677) and $8500 \pm 145{ }^{14} \mathrm{C}$ yr BP* (ANU-1676) could have been reworked upward from more seaward barrier as argued for Moruya. 5) Thick backbarrier sand wedge interfingering with 4). 6) Nearshore shelly sand facies which overlies 4) and coarsens upward into tabular beach sand unit. Nearshore shelly sand is associated with sedimentary regression which formed "core" 
of Outer Barrier at present sea level. 7) Barrier is surmounted by 3 massive, cross-bedded sand bodies up to $30 \mathrm{~m}$ thick. Two vegetated dune ridges, I and II, possess different degrees of soil development indicating discrete phases of deposition, followed by currently active phase III which is at least $300{ }^{14} \mathrm{C}$ yr old (ANU-1331).

\section{SUMMARY}

Episodic history of Holocene barriers in NSW is suggestive of synchronous processes initiating phases of marine regression or beach-ridge progradation, vertical foredune accretion, foredune erosion and destruction, transgressive dune mobilization, and vegetative colonization. Termination of postglacial marine transgression ca $6000{ }^{14} \mathrm{C}$ уr вР* on this coast and subsequent attainment of beach-nearshore equilibrium may explain rapid transfer of sand from offshore to onshore. In comparison with other coastal barriers, which have been documented by ${ }^{14} \mathrm{C}$ dating (eg, Bernard et al, 1962, Galveston I.), bay barriers of SE Australia exhibit more diverse age structures in that they commenced and generally ceased progradation earlier than $\mathrm{N}$ Hemisphere counterparts, although rates of progradation were similar at times of max accretion (3 to $6 \mathrm{~m} / \mathrm{yr}$; Thom et al, 1978). Subsequent episodes may be best explained by secular variations in storminess and wave climate in Tasman Sea. Extent to which these variations correlate with mid to late Holocene global changes in climate (and/or slight undocumented changes in sea level) remains unknown.

\section{REFERENCES}

Bernard, H A, Le Blanc, R J, and Major, C F, 1962, Recent and Pleistocene geology of Southeast Texas, in: Rainwater, E H and Zingula, R P (eds), Geology of the Gulf Coast and Central Texas and guidebook of excursions: Houston, Houston Geol Soc, p $175-224$.

Bloom, A L, Broecker, W S, Chappell, John, Matthews, R S, and Mesolella, K J, 1974, Quaternary sea level fluctuations on a tectonic coast: new $\mathrm{Th}^{230} / \mathrm{U}^{234}$ dates from the Huon Peninsula, New Guinea: Quaternary Research, v 4, p 185-205.

Curray, J R, Emmel, F J, and Crampton, P J S, 1969, Holocene history of a strand plain, lagoonal coast, Nayarit, Mexico, in: Lagunas Costeras, un Simposio, Mexico, UNAM-UNESCO, p 61-100.

Gillespie, R and Polach, H A, 1977, The suitability of marine shells for radiocarbon dating of Australian prehistory, in: Internatl conf on radiocarbon dating 9th, Proc, Univ California, Los Angeles and San Diego, in press.

Langford-Smith, T and Thom, B G, 1969, Coastal morphology of New South Wales: Geol Soc Australia Jour, v 16, p 572-580.

Ly, C K, 1976, Depositional and mineralogical studies of Quaternary sedimentation in the Newcastle-Port Stephens area of New South Wales: unpub PhD thesis, Univ Newcastle, Newcastle, New South Wales, Australia.

Stuiver, M and Polach, H A, 1977, Reporting of ${ }^{14} \mathrm{C}$ data: a discussion: Radiocarbon, v 19, p 358-363.

Thom, B G, 1965, Late Quaternary coastal morphology of the Port Stephens-Myall Lakes area, NSW: Royal Soc New South Wales Jour, v 98, p 23-36.

Thom, B G, Polach, H A, and Bowman, G M, 1978, Holocene age structure of coastal sand barriers in New South Wales, Australia: Occ monos, Dept Geog, Fac Military Studies, Univ New South Wales, 86 p. 